\title{
Impact Of Work Place Stress On Health Among Public And Private Bank Employees
}

\author{
V.M.Suryaprakash, M.Hema Mary
}

\begin{abstract}
Stress is pervasive in nature in the contemporary world, every human being has suffered by stress in various dimensions according to their level of standard of living. Stress has the power to kill the mankind but it is invincible so people do not have adequate awareness towards it. It plays a vital role in individual lives as well as surroundings. In the modern technological world all are busy towards grabbing something to hold their status and to attain their goals. They don't have time to think about their stress due to time constraints and they keep going with it and finally the accumulated stress bursts out which has reflection on physical and mental health. This is most common among employees of banking sector because of the global competition. Bank employees have high stress because of the work nature and they have to work very prudently. This article obviously focuses on exploring the sources of stress, it's influence on employees' health and thereby the impact. The findings of this study revealed that public sector bank employees are relatively less stressed than private bank employees. In private sector, Diabetes and Hypertension are common impact of stress irrespective of gender and employees aged between 41 to 50 years are mostly affected by physical health issues and the employees aged between 21 years to 40 are affected psychological health issues and finally women employees are highly affected by stress when compared to male in private banking sector.
\end{abstract}

Key words: stress, health, physical, psychological and workplace.

\section{INTRODUCTION}

Workplace stress will arise when there is a mismatch between the requirements of the role, employee proficients and resources and support system available. It is about response of employee who deals with the situation. These responses could vary from person to person. Few take it as positive and most of them feel it negative. Some stress is expected and can be a positive force in our lives, called the eustress. In fact, it provides the energy and motivation to meet the daily challenges both at home and at the workplace. On the other hand a feeling of negative stress typically increases when people believe that the demands of a situation are greater than their capability to deal with, preventing them from being productive. Some may find it hard to concentrate, make decisions, and feel confident and it can also have long term impact on physical and mental health.

The banking sector encompasses highly stressful work nature when compared to the other industry because they deal with money and it is very sensitive possessions for all

Revised Manuscript Received on April 19, 2019.

V.M.Suryaprakash, Ph.D Full-Time Research Scholar, Department of Management Studies, AVS College of Arts \& Science, Salem, Tamilnadu, India.

Dr.M.Hema Mary, Assistant Professor, Department of Management \& Research, AVS College of Arts \& Science, Salem, Tamilnadu, India. and none is ready to lose it. For the past two decades, the banking industry had endured rapid and remarkable changes in policies and regulations after Liberalization, Globalization and Privatization (LPG). The arrivals of new technological revolution are also walk together with globalization. LPG leads to entrance for private sector banks, introduction of new technologies leading to several changes, contributing to high level of stress of the employees in the banking sector. Privatization policies have drastically changed conventional patterns in all sectors. Especially in banking industry, $\mathrm{n}$ a county like India with huge population, nearly 310 million saving accounts exist in banks till date. Ultimately, the bank employees undergo lot of stress because they deal with public and also with higherups. After globalization and the arrival of foreign banks, each and every bank is competing with one other for retaining its existing customers and acquiring new customers. In this global competition among the banks, their employees are highly affected by work place stress and reflected on their physical and mental health leading to a variety of health \& mental issues such as Frequent Headache, Chronic back pain, Hypertension, Fatigue or tiredness, Indigestion, Diabetes, Absence of mind, Low memory retention, Anxiety, Poor anger management, low self-esteem, insomnia, etc. And finally Pinnacle of stress drives the employee to commit suicide in extreme cases.

Definition: "The adverse reaction people have to excessive pressures or other types of demand placed on them at work."

Sources of work place stress

$>\quad$ Increasing workload

$>\quad$ Narrow promotional opportunities

$>\quad$ Job insecurity

$>$ Changes in Organizational Climate

$>$ Stringent deadlines/targets

$>\quad$ Lack of autonomy

$>\quad$ Work monotony

$>$ Over-supervision / Meticulously monitoring

$>$ Discrimination / Gender bias

$>\quad$ Lack of training to adopt technological changes

\section{EFFECT OF STRESS IN HEALTH RELATED ISSUES.}

I. Physical health issues

- $\quad$ Recurring Headache

- Chronic back pain

Published By: 


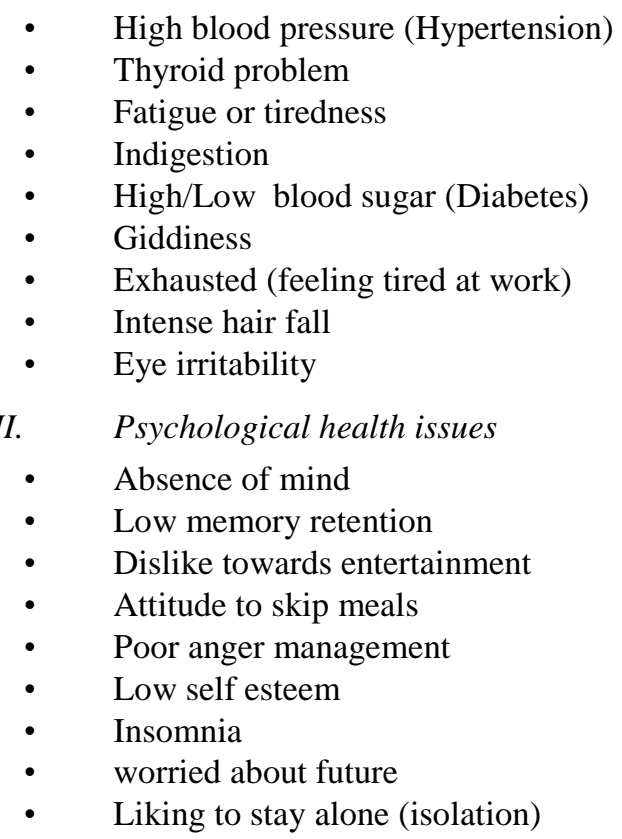

\section{OBJECTIVE OF THE STUDY:}

$\checkmark \quad$ To analyse the impact of stress on bank employees' health.

$\checkmark \quad$ To identify which banking sector is highly affected by health issues - public or private.

$\checkmark \quad$ To identify which age category has been dominantly affected by health issues.

$\checkmark \quad$ To identify which gender has been highly affected by health problem

\section{SIGNIFICANCE OF STUDY:}

Bank employees are predominantly affected by stress when compared to other industry because of dynamic technological advancement in this sector, technological advancement has given hands to employees to do job easily but it causes stress sometimes, when employees are unable to cope up with the advancement. Now competition in banking sector are in zenith, so employees are forced to work hard irrespective of time and enthusiasm, at some point it causes extreme stress and its effects directly replicate on employee physical and mental health, so they fail to balance their work and family eventually. However some employees can cope up with it and they can go on. But residuals are wedged at one point and they are lost with dilemma whether to continue the present job or switch over to another. When the employees are in stress it not only affects the individuals, it has the influence to directly affect overall productivity of the organization.

\section{REVIEW OF LITERATURE}

Stress can also have varied consecutive duration's, such as acute and chronic stress. According to Oxington, (2005), chronic stress includes stress that is not short term. Health concerns, lingering problems and financial difficulties may be sources of chronic stress. Acute stress on the other hand is caused by a reaction to a short-lived, urgent threat. This threat can either be real or perceived.

Erkutlu and Chafra (2006) opine that, when stress exerts too much pressure, an individual becomes disorganized, disoriented and cannot cope up adequately, resulting in stress related problems, psychological and physical unhealthiest.

Wyatt-Watson (2002), in their annual survey identified that mental health disorders can also put employees at greater risk of other illnesses, or increase the gravity, duration and likelihood of recurrence of chronic illnesses. For example, individuals who suffer from depression and/or anxiety are at greater risk of developing cardiovascular disease and it would affect the employee overall job performance.

\section{LIMITATION OF THE STUDY}

$>$ Research was grounded on the questionnaire method

D Sample size was restricted to 120

$>\quad$ Convenience sampling technique was engaged and it was restricting to only public and private bank employees in Salem district. So the findings of these studies are limited to Salem district only due to cost and time constraints.

\section{RESEARCH METHODOLOGY}

Data collection: Primary and secondary data are collected for this research, primary data was collected through a well-structured questionnaire which was personally handed out to the respondents during their break timings to seek their responses. Secondary data was collected with the help of online sources, text books, articles, magazines and newspapers. Convenient sampling technique was used for data collection.

Sample size: For the research purpose the samples were collected from 120 private and public bank employees in Salem district.

Tools: Simple percentage analysis, Chi-Square and ANOVA are used for analysis of data with the help of SPSS. 
International Journal of Engineering and Advanced Technology (IJEAT) ISSN: 2249 - 8958, Volume-8 Issue-5C, May 2019 India

\begin{tabular}{|c|c|c|}
\hline \multicolumn{3}{|c|}{ Data analysis and interpretation } \\
\hline Demographic details & Frequency & Percent \\
\hline \multicolumn{3}{|l|}{ Gender } \\
\hline Male & 52 & 43.3 \\
\hline Female & 68 & 56.7 \\
\hline Total & 120 & 100.0 \\
\hline Bank & Frequency & Percent \\
\hline Private & 68 & 56.7 \\
\hline Public & 52 & 43.3 \\
\hline Total & 120 & 100.0 \\
\hline Age & Frequency & Percent \\
\hline 20-30 Years & 19 & 15.8 \\
\hline $31-40$ Years & 38 & 31.7 \\
\hline 41-50 Years & 51 & 42.5 \\
\hline 51 Years \& Above & 12 & 10.0 \\
\hline Total & 120 & 100.0 \\
\hline Work experience & Frequency & Percent \\
\hline $0-5$ Years & 16 & 13.3 \\
\hline 6-10 Years & 17 & 14.3 \\
\hline 11-15 Years & 26 & 22.3 \\
\hline 16-20 Years & 28 & 23.3 \\
\hline 21 Years \& Above & 32 & 26.7 \\
\hline Total & 120 & 100.0 \\
\hline
\end{tabular}

\section{Interpretation}

The above table reveals that $43 \%$ are male and $57 \%$ are female. $16 \%$ of the respondents belong to the age category of 20-30 years, $32 \%$ fall between 31 to 40 years, $42 \%$ between 41-50years and $10 \%$ are above 51 years of age. $57 \%$ of respondents are from private banks and $43 \%$ respondent are from public banks. $13 \%$ respondents possess work experience of $0-5$ years, $14 \%$ has 6-10 years experiences, $22 \%$ with $11-15$ years, $23 \%$ have $16-20$ years and $27 \%$ possess more than 21 years of experience.

\section{CHI SQUARE ANALYSIS}

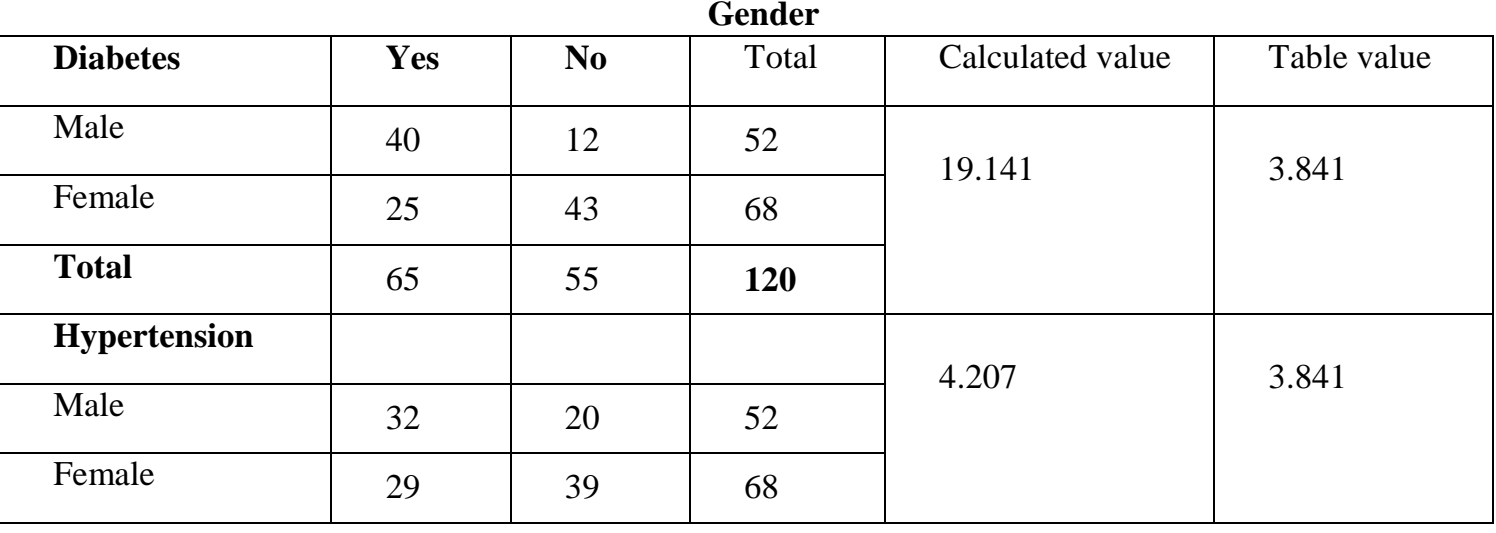


International Conference on Recents Advancements in Engineering and Technology (ICRAET-18) |15th and 16th March 2019|Siddhartha Institute of Technology \& Sciences, Telangana, India

\begin{tabular}{|l|c|c|c|c|c|}
\hline Total & $\mathbf{6 1}$ & $\mathbf{5 9}$ & $\mathbf{1 2 0}$ & & \multirow{2}{*}{7.539} \\
\cline { 1 - 4 } Thyroid & & & & \multirow{2}{*}{3.841} \\
\cline { 1 - 4 } Male & 12 & 40 & 52 & & \\
\cline { 1 - 4 } Female & 4 & 64 & 68 & \\
\hline
\end{tabular}

\section{Interpretation:}

From the above table it is found that calculated value > rejected. Diabetes, Hypertension and thyroid are significantly related to gender. table value at $5 \%$ level of significance.null hypothesis is

\begin{tabular}{|c|c|c|c|c|c|}
\hline \multicolumn{6}{|c|}{ Age } \\
\hline Diabetes & Yes & No & Total & Calculated value & Table value \\
\hline 20-30 Years & 8 & 11 & 19 & \multirow{5}{*}{10.219} & \multirow{5}{*}{7.815} \\
\hline $31-40$ Years & 23 & 15 & 38 & & \\
\hline 41-50 Years & 23 & 28 & 51 & & \\
\hline 51 Years \& Above & 11 & 1 & 12 & & \\
\hline Total & 65 & 55 & 120 & & \\
\hline \multicolumn{4}{|l|}{ Hypertension } & \multirow{6}{*}{10.149} & \multirow{6}{*}{7.815} \\
\hline 20-30 Years & 4 & 15 & 19 & & \\
\hline 31-40 Years & 18 & 20 & 38 & & \\
\hline 41-50 Years & 31 & 20 & 51 & & \\
\hline 51 Years \& Above & 8 & 4 & 12 & & \\
\hline Total & 61 & 59 & 120 & & \\
\hline
\end{tabular}

hypothesis is rejected. It is inferred that Diabetes and

\section{Interpretation}

Hypertension are significantly related to age.

From the above table it is found that calculated value >

II. ANOVA Table

table value at $5 \%$ level of significance. Hence null

\begin{tabular}{|c|c|c|c|c|c|c|}
\hline \multicolumn{2}{|l|}{ Physical health issues } & $\begin{array}{l}\text { Sum of } \\
\text { Squares }\end{array}$ & df & $\begin{array}{l}\text { Mean } \\
\text { Square } \\
\end{array}$ & $\mathbf{F}$ & Sig. \\
\hline \multicolumn{2}{|c|}{\begin{tabular}{|l|ll} 
Chronic Neck and body & $\begin{array}{l}\text { Between } \\
\text { pain * Bank }\end{array}$ & Groups
\end{tabular}} & 15.445 & 1 & 15.445 & 14.790 & .000 \\
\hline & Within Groups & 123.222 & 118 & 1.044 & & \\
\hline & Total & 138.667 & 119 & & & \\
\hline \multirow{3}{*}{$\begin{array}{l}\text { Frequent Headache * } \\
\text { Bank }\end{array}$} & $\begin{array}{l}\text { Between (Combined) } \\
\text { Groups }\end{array}$ & 1.064 & 1 & 1.064 & .965 & .328 \\
\hline & Within Groups & 130.136 & 118 & 1.103 & & \\
\hline & Total & 131.200 & 119 & & & \\
\hline \multirow[t]{3}{*}{ Acidity * Bank } & $\begin{array}{l}\text { Between } \quad \text { (Combined) } \\
\text { Groups }\end{array}$ & 12.860 & 1 & 12.860 & 12.377 & .001 \\
\hline & Within Groups & 122.606 & 118 & 1.039 & & \\
\hline & Total & 135.467 & 119 & & & \\
\hline
\end{tabular}


International Journal of Engineering and Advanced Technology (IJEAT) ISSN: 2249 - 8958, Volume-8 Issue-5C, May 2019 India

\begin{tabular}{|c|c|c|c|c|c|c|}
\hline \multirow[t]{3}{*}{$\begin{array}{l}\text { Feeling tired at work } \\
\text { Bank }\end{array}$} & $\begin{array}{l}\text { Between } \\
\text { Groups }\end{array}$ & 4.672 & 1 & 4.672 & 13.383 & .000 \\
\hline & Within Groups & 41.195 & 118 & .349 & & \\
\hline & Total & 45.867 & 119 & & & \\
\hline \multirow[t]{3}{*}{ Intense hair fall $*$ Bank } & $\begin{array}{l}\text { Between } \\
\text { Groups }\end{array}$ & 14.871 & 1 & 14.871 & 5.989 & .016 \\
\hline & Within Groups & 292.995 & 118 & 2.483 & & \\
\hline & Total & 307.867 & 119 & & & \\
\hline \multirow[t]{3}{*}{ Eye irritability * Bank } & $\begin{array}{l}\text { Between } \quad \text { (Combined) } \\
\text { Groups }\end{array}$ & .918 & 1 & .918 & .951 & 332 \\
\hline & Within Groups & 113.882 & 118 & .965 & & \\
\hline & Total & 114.800 & 119 & & & \\
\hline
\end{tabular}

\section{Inference:}

From the above table it is found that the factors like chronic neck and body pain $(\mathrm{F}=14.790)(\mathrm{P}=.000)$, Acidity $(\mathrm{F}=12.377) \quad(\mathrm{P}=.001)$, Feeling tired at work $(\mathrm{F}=13.383)$ $(\mathrm{P}=.000)$ and Intense hair fall $(\mathrm{F}=5.989)(\mathrm{P}=.016)$ are statistically significant at $5 \%$ level of significance.

\begin{tabular}{|c|c|c|c|c|c|c|c|}
\hline \multicolumn{3}{|l|}{ Psychological health issues } & $\begin{array}{l}\text { Sum } \\
\text { Squares }\end{array}$ & $\mathrm{df}$ & $\begin{array}{l}\text { Mean } \\
\text { Square }\end{array}$ & $\mathrm{F}$ & Sig. \\
\hline \multirow[t]{3}{*}{ Attitude to skip meals * Bank } & $\begin{array}{l}\text { Between } \\
\text { Groups }\end{array}$ & (Combined) & 2.030 & 1 & 2.030 & 1.051 & .307 \\
\hline & \multicolumn{2}{|c|}{ Within Groups } & 227.837 & 118 & 1.931 & & \\
\hline & \multicolumn{2}{|l|}{ Total } & 229.867 & 119 & & & \\
\hline \multirow[t]{3}{*}{ Feeling panicky * Bank } & \begin{tabular}{|l} 
Between \\
Groups
\end{tabular} & (Combined) & 3.861 & 1 & 3.861 & 2.492 & .117 \\
\hline & \multicolumn{2}{|c|}{ Within Groups } & 182.805 & 118 & 1.549 & & \\
\hline & \multicolumn{2}{|l|}{ Total } & 186.667 & 119 & & & \\
\hline \multirow[t]{3}{*}{ Liking to stay alone * Bank } & $\begin{array}{l}\text { Between } \\
\text { Groups }\end{array}$ & (Combined) & 10.672 & 1 & 10.672 & 7.443 & .007 \\
\hline & \multicolumn{2}{|c|}{ Within Groups } & 169.195 & 118 & 1.434 & & \\
\hline & \multicolumn{2}{|l|}{ Total } & 179.867 & 119 & & & \\
\hline \multirow[t]{3}{*}{ Worried about future $*$ Bank } & $\begin{array}{l}\text { Between } \\
\text { Groups }\end{array}$ & (Combined) & 22.241 & 1 & 22.241 & 12.324 & .001 \\
\hline & \multicolumn{2}{|c|}{ Within Groups } & 212.959 & 118 & 1.805 & & \\
\hline & \multicolumn{2}{|l|}{ Total } & 235.200 & 119 & & & \\
\hline \multirow[t]{3}{*}{ Low Self Esteem * Bank } & \begin{tabular}{|l} 
Between \\
Groups
\end{tabular} & (Combined) & 1.759 & 1 & 1.759 & 1.214 & .273 \\
\hline & \multicolumn{2}{|c|}{ Within Groups } & 171.041 & 118 & 1.449 & & \\
\hline & \multicolumn{2}{|l|}{ Total } & 172.800 & 119 & & & \\
\hline
\end{tabular}

\section{Inference:}

From the above table it is found that the factors like Liking to stay alone $(\mathrm{F}=7.443)(\mathrm{P}=.007)$ and Worried about future $(\mathrm{F}=12.324)(\mathrm{P}=.001)$ are statistically significant at $5 \%$ level of significance. Therefore null hypothesis is rejected at $5 \%$ level of significance. Hence it is concluded that these psychological health issues are significantly noticed among the employees of banking sector
Therefore null hypothesis is rejected at 5\% level of significance. Hence it is concluded that chronic neck and body pain, acidity, feeling tired at work and intense hair fall are significant health issues prevalent among employees of banking sector. 


\section{CONCLUSION}

This research was carried out intending for a comparative analysis on impact of work place stress on health among public and private bank employees. Stress has been experienced by both public and private sector but the findings of this research revealed that the private banks' employees are more stressed when compared to the public sector banks. Even though the public sector bank employees are also stressed, it has affected their physical and mental health, relatively lesser. In private sector, stress impacts on employees' health directly leading to health issues such as Diabetes and Hypertension, which are most common among them irrespective of gender. They are affected by both physical and psychologically corresponding to the age. The employees aged between 41 to 50 years are mostly affected by physical health issues and the employees aged between 21 years to 40 are affected psychological health issues and finally women employees are highly affected by stress when compared to male in private banking sector. This study concludes that the stress can affect the employees' health and the result could contribute negatively on productivity of the organization.

\section{REFERENCES}

1 http://ir.knust.edu.gh/bitstream/123456789/4799/1/Nnuro ,\%20Edward\%20Kwaku.pdf

2 https://www.researchgate.net/publication/290020721_Oc cupational_stress_in_bankingsector

3 https://esource.dbs.ie/bitstream/handle/10788/2336/mba_ divakar_j_2015.pdf?sequence=1\&isAllowed=y

4 https://www.researchgate.net/publication/313241568_Oc cupational_Stress_and_its_impact_on_Physical_and_Psy chological_Health_of_Employees_in_Private_Education al_Organizations_Management_Strategies

5 http://www.scholarshub.net/ijcms/vol6/issue2/Paper_08. pdf

\section{AUTHORS PROFILE}

V.M.Suryaprakash, MBA, PhD, Full time research scholar, AVS College of Arts \& Science, Salem, Tamil Nadu, India. Previous paper publications include (2019March) A study on the stress management strategies among bank employees E- ISSN- 2348-1269, print ISSN -

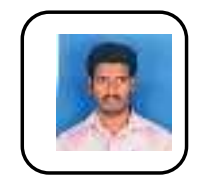
stressors among women bank employees of selected banks in Salem district, Tamil Nadu. E ISSN - 2348-1269 P ISSN - 2349-5138; (cosmos impact factor- 4.236) ( impact factor- 5.75); (2018-August) A study on the impact of stress among bank employees and it's influence towards employee engagement with reference to selected banks in Attur, Salem District E ISSN- 2348-1269, P ISSN 2349-5138 (impact factor- 5.75); (2018) Impact of positive and negative job stress with special reference to bank employees ISBN- 978-93-83191-29-1;

Dr. M. Hema Mary, Assistant Professor, Department of Management Studies, AVS College of Arts \& Science, Salem, Tamil Nadu, India. Few recent paper publications include (2017 September) Online shopping - The Boon and Bane in cashless economy- ISSN: 2320-4168; (2017 February) Role of learning and development in facilitating a happy organisation ISSN online -2320-9704; (2017 February) HR strategies to Hone innovative practices in SME's and start up companies. ISSN -2321-5739. 